\title{
HUBUNGAN ANTARA PERSEPSI TERHADAP IKLAN ROKOK DENGAN PERILAKU MEROKOK PADA REMAJA
}

\author{
Annisa Nurul Afif ${ }^{1}$, Kamsih Astuti ${ }^{2}$ \\ ${ }^{12}$ Universitas Mercu Buana Yogyakarta \\ 2tutik.umby@gmail.com
}

\begin{abstract}
Abstrak
Penelitian ini bertujuan untuk mengetahui hubungan antara persepsi terhadap iklan rokok dengan perilaku merokok pada remaja. Hipotesis yang diajukan dalam penelitian ini adalah ada hubungan positif antara persepsi terhadap iklan rokok dengan perilaku merokok pada remaja. Subjek dalam penelitian ini adalah siswa SMK N Sedayu Bantul sebanyak 50 siswa. Pengumpulan data dilakukan dengan menggunakan skala, yaitu skala perilaku merokok dan skala persepsi terhadap iklan rokok. Analisis data menggunakan korelasi product- moment dari Pearson. Hasil analisis menunjukkan bahwa ada hubungan positif yang signifikan antara persepsi terhadap iklan rokok dengan perilaku merokok pada remaja, yaitu $r=0,626 \mathrm{p}<0,05$. Hal tersebut menunjukkan bahwa hipotesis yang diajukan diterima yang berarti bahwa jika persepsi terhadap iklan rokok positif maka perilaku merokok pada remaja cenderung tinggi, sebaliknya jika persepsi terhadap iklan rokok negative maka perilaku merokok pada remaja akan cenderung rendah. Sumbangan efektif persepsi iklan rokok terhadap perilaku merokok sebesar 39,2\% artinya masih terdapat beberapa faktor lain yang dapat mempengaruhi meningkatnya perilaku merokok pada remaja sebesar $60,8 \%$.
\end{abstract}

Kata Kunci : persepsi terhadap iklan rokok, perilaku merokok

\section{THE RELATIONSHIP BETWEEN PERCEPTION OF CIGARETTE ADVERTISING AND SMOKING BEHAVIOR IN YOUTH}

\author{
Annisa Nurul Afif ${ }^{1}$, Kamsih Astuti ${ }^{2}$ \\ ${ }^{12}$ Universitas Mercu Buana Yogyakarta \\ ${ }^{2}$ tutik.umby@gmail.com
}

\begin{abstract}
This study aims to find out the relationship between perceptions of cigarette advertising and smoking behavior in adolescents. The hypothesis proposed in this study were there is a positive relationship between the perception of cigarette advertising and smoking behavior in adolescents. The subjects of the study were 50 students of SMK N Sedayu Bantul. The data collection was done using the scale of smoking behavior and the scale of perception of cigarette advertising. The data analysis used product-moment correlation from Pearson. The results of the analysis show that there is a significant positive relationship between perceptions of cigarette advertising and smoking behavior in adolescents, with the value of $r=0.626 p<0.05$. This shows that the proposed hypothesis is accepted which means that if the perception of cigarette advertising is positive, smoking behavior in adolescents tends to be high. Whereas if the perception of cigarette advertising is negative then smoking behavior in adolescents will tend to be low. The effective contribution of the perception of cigarette advertising to smoking behavior is $39.2 \%$, which means there are still several other factors that can affect the increase of smoking behavior in adolescents by $60.8 \%$.
\end{abstract}

Keywords: perception of cigarette advertising, smoking behavior

\section{PENDAHULUAN}

Remaja adalah suatu masa transisi atau masa peralihan dari fase anak-anak menuju fase dewasa. Salah satu karakteristik umum perkembangan remaja menurut Asrori (2010) adalah memiliki rasa ingin tahu yang 
tinggi (high curiosity). Akibatnya, tidak jarang secara sembunyi-sembunyi, remaja mencoba untuk melakukan hal- hal yang berkaitan dengan aktivitas yang dilakukan oleh orang dewasa. Remaja ingin membuktikan kalau sebenarnya dirinya mampu berbuat seperti yang dilakukan orang dewasa. Namun pada kenyataannya yang terjadi adalah para remaja seringkali dihubungkan dengan mitos dan stereotip mengenai penyimpangan dan ketidakwajaran (Hurlock, 2000). Salah satu contoh penyimpangan yang banyak ditemui pada remaja adalah perilaku merokok (Hurlock, 2000).

Menurut Levy (dalam Andarini \& Purnamasari, 2011) perilaku merokok adalah suatu aktivitas yang dilakukan seseorang berupa membakar rokok dan menghisapnya serta dapat menimbulkan asap yang dapat terhisap oleh orang-orang yang ada di sekitarnya. Perilaku merokok dikalangan remaja merupakan kegiatan yang "fenomenal", artinya meskipun sudah diketahui akibat dari merokok tetapi jumlah remaja yang merokok bukan semakin menurun tetapi semakin meningkat. Akibatnya, masalah perilaku merokok khususnya pada remaja sangat sulit untuk dipecahkan. Remaja yang merokok dapat mengancam masa depan kesehatan dan keperibadian remaja tersebut.

Remaja yang sudah memulai merokok akan mengalami kecanduan untuk terus merokok, yang mengakibatkan terganggunya kesehatan dengan berbagai penyakit kronis misalnya, tubuh mengalami kekurangan oksigen (O2), penyempitan pada pembuluh darah di seluruh tubuh, meningkatkan tekanan darah, penyakit jantung, stroke, gangguan kehamilan dan janin, impotensi, kanker, gangguan saluran pernapasan, hingga menyebabkan kematian (Partodiharjo dalam Andarini \& Purnamasari, 2011). Hasil riset Larson dkk. (dalam Komasari \& Helmi, 2000) menemukan bahwa sensitivitas ketajaman penciuman dan pengecapan para perokok berkurang bila dibandingkan dengan nonperokok.

Dilihat dari sisi ekonomi, merokok pada dasarnya „membakar uang ${ }^{\text {ee }}$ apalagi jika hal tersebut dilakukan remaja yang belum mempunyai penghasilan sendiri. Berdasarkan hasil wawancara yang dilakukan pada tanggal 9 Febuari 2014 oleh peneliti terhadap 3 orang anak SMA X didapatkan hasil bahwa mereka merokok berkisar 1 bungkus rokok/perhari. Harga rokok perbungkus dengan harga berkisar Rp 13. 000,- (tiga belas ribu rupiah). Jika seorang perokok menghabiskan satu bungkus rokok perhari, maka dalam satu minggu perokok mengeluarkan biaya Rp 91 . 000 (sembilan puluh satu ribu rupiah), maka dalam sebulan menghabiskan biaya $\mathrm{Rp} 2$. 370.000,- (dua juta tiga ratus tujuh puluh ribu rupiah), dan dalam setahun mengeluarkan biaya sebesar Rp 32 760.000,- (tiga puluh dua juta tujuh ratus enam puluh ribu rupiah).

Dilihat dari sisi orang di sekelilingnya, merokok menimbulkan dampak negatif bagi perokok pasif misalnya, meningkatnya kerja dari susunan syaraf pusat dan susunan syaraf simpatetis sehingga mengakibatkan tekanan darah meningkat dan detak jantung bertambah cepat. Resiko yang ditanggung perokok pasif lebih berbahaya daripada 
perokok aktif karena adanya daya tahan terhadap zat- zat yang berbahaya sangat rendah (Safarino, dalam Komasari \& Helmi 2000).

Besarnya bahaya yang ditimbulkan oleh rokok terhadap aspek kehidupan remaja yang ditinjau dari segi kesehatan dan keperibadian remaja, maka dari itu perlunya dilakukan penelitian untuk mengurangi atau mencegah semakin bertambahnya perilaku merokok di kalangan remaja.

Untuk itu secara fisik kesehatan remaja perlu mendapatkan perhatian yang cukup signifikan dari pemerintah. Namun, berdasarkan penelitian yang dilakukan oleh Komasari \& Helmi (2000) yang menyatakan bahwa usia memulai aktivitas merokok yang dilakukan dikalangan remaja semakin hari semakin bertambah muda.

Di daerah Yogyakarta sebanyak 16 persen pelajar SMP dan SMA adalah perokok. Dari jumlah tersebut, 12 persen merupakan perokok eksperimenter dan 4 persen perokok reguler. Eksperimenter adalah kelompok pelajar yang beberapa kali mencoba dengan teman, sedangkan perokok reguler ialah kelompok pelajar yang merokok rutin setiap hari. Survei tersebut dilakukan Quit Tobacco Indonesia, Fakultas Kedokteran (FK) UGM, terhadap 2.015 siswa SMP dan SMA di Kota Yogyakarta. Dari hasil wawancara dengan beberapa siswa, mereka mengatakan bahwa sebanyak kurang lebih $80 \%$ dari jumlah siswa laki-laki kelas XI dan XII atau 89 siswa disana adalah perokok, mereka merokok baik pada saat jam-jam istirahat maupun setelah pulang sekolah (Hasanah \& Sulastri, 2011).
Dari data di atas menunjukkan bahwa perilaku merokok remaja tidak pernah surut dari tahun ke tahun. Hal ini dikarenakan adanya faktor-faktor yang menjadi alasan mengapa remaja merokok. Muetadin (2002) mengemukakan bahwa faktor-faktor yang mempengaruhi perilaku merokok pada remaja adalah pengaruh orangtua, pengaruh teman, faktor kepribadian, dan pengaruh iklan.

Menurut Belch dan Belch (dalam Loviana, 2012) persepsi terhadap iklan meliputi reaksi terhadap faktor iklan seperti kreativitas, efek gambar, warna, dan intonasi suara. Persepsi terhadap iklan dapat berupa hal yang positif maupun negatif. Biasanya dengan adanya model/ selebritas akan membawa konsumen kepada persepsi yang positif terhadap suatu produk sehingga kesadaran akan produk tersebut dapat bertambah menjadi lebih baik. Berdasarkan uraian di atas persepsi terhadap iklan rokok adalah bagaimana seseorang melihat dan mengartikan informasi tentang produk rokok yang telah disajikan oleh media-media tertentu. Berdasarkan Studi Keterpajanan Iklan dan Sponsor terhadap kognitif, afeksi, dan perilaku merokok remaja, yang dilakukan Universitas Hamka dan Komnas Anak pada tahun 2007 mencatat sebanyak 99,7\% dari 353 siswa SMP dan sekolah lanjutan atas di DKI Jakarta mengaku menonton iklan rokok di televisi dan $86,7 \%$ melihat iklan rokok.

Menurut survey Kementrian Kesehatan Republik Indonesia Prof Tjandra, 89,3\% remaja Indonesia merokok karena melihat iklan. Baik itu di billboard, media cetak, elektronik, ataupun televisi. Prof Tjandra 
menerangkan, jumlah perokok yang berpendidikan tinggi sekitar 21,5\% dan 23,3 $\%$ berpendidikan rendah. Selanjutnya, 32,3\% perokok tergolong miskin dan 24, $3 \%$ perokok yang tergolong kaya "dapat dilihat, perokok itu adalah orang yang tidak berpendidikan tinggi dan kaya. Melalui media dan publikasi, orang yang tidak berpendidikan akan mudah terpengaruh untuk merokok. Oleh sebab itulah media sangat berperan untuk pencerdasan anak bangsa," (Kedaulatan Rakyat, 2014).

Menurut Salafudin (dalam Ariyani, 2004) menyatakan bahwa persepsi terhadap rokok terbentuk melalui melihat, mendengar, dan membaca berdasarkan pengalaman. Iklan yang ada di televisi dan media massa, akan mempengaruhi remaja untuk meniru dan mengikuti perilaku model dalam memperkenalkan produk rokok tersebut, ditambah dengan adanya image yang dibentuk oleh model dalam iklan rokok sehingga terlihat seakan orang yang merokok adalah orang yang sukses, keren, dewasa dan tangguh yang dapat melalui rintangan apapun. Banyaknya iklan yang beredar saat ini selalu bertujuan untuk menciptakan image yang baik bagi perokok padahal kenyataannya dalam rokok terdapat bahan kimia yang berbahaya bagi kesehatan.

Persepsi yang positif terhadap merokok akan memberikan keyakinan pada diri setiap individu bahwa aktifitas merokok itu baik dan pada akhirnya individu tersebut meningkatkan perilaku merokok (Aeni \& Astuti, 2009). Ramaja akan terus merokok apabila remaja merasa bahwa dengan merokok banyak memberikan kepuasan psikologis pada dirinya, serta dapat meningkatkan kepercayaan diri remaja dalam pergaulan di lingkungan teman sebayanya, agar mereka terlihat keren, tangguh, dewasa seperti model yang diperankan dalam iklan rokok tersebut, yang mengakibatkan intensitas penggunaan rokok dikalangan remaja semakin meningkat tanpa peduli efek yang akan terjadi pada jangka waktu yang lebih pangjang terhadap dirinya.

Hasil survey tahun 2007-2008 yang dilakukan oleh Komisi Nasional Perlindungan Anak (Komnas PA) (dalam Iskandar, 2011) mendapati bahwa, salah satu kriteria pria jantan dan perkasa menurut kebanyakan responden adalah mereka yang merokok. Dan $83,7 \%$ perokok anak akibat pengaruh kuat iklan di media massa yang menonjolkan kejantanan dan kegagahan. Hal tersebut didukung dengan penelitian Ariani (2011) dilakukan di Madrasah Aliyah Negeri 2 Boyolali bahwa terdapat hubungan yang signifikan antara dukungan iklan rokok dengan perilaku merokok pada siswa.

Dari uraian di atas dapat disimpulkan bahwa iklan rokok akan membuat remaja memiliki persepsi tertentu terhadap rokok sehingga akan mempengaruhi perilaku merokok pada remaja. Hal ini dikarenakan remaja yang masih dalam proses pencarian identitas diri dan keadaan emosi yang masih labil akan mudah dipersuasi oleh iklan rokok tersebut. Akibatnya, remaja akan terpengaruh untuk merokok. Berdasarkan latar belakang tersebut di atas, maka penyusun dapat merumuskan suatu permasalahan, apakah ada hubungan antara persepsi terhadap iklan rokok 
dengan perilaku merokok pada remaja?

\section{METODE}

\section{Subjek Penelitian}

Subjek yang digunakan dalam penelitian ini adalah remaja laki-laki yang berusia antara 15-18 tahun di 50 SMK N 1 Sedayu Bantul. Jumlah subjek penelitian ini sebanyak 50 subjek yang merokok.

\section{Metode Pengumpulan Data}

Metode pengumpulan data pada penelitian ini berupa skala adalah:

\section{Skala Perilaku Merokok}

Skala perilaku merokok merupakan skala yang disusun berdasarkan aspek-aspek perilaku merokok yang dikemukakan oleh Aritonang (1997) yaitu fungsi merokok, intensitas merokok, waktu merokok dan tempat merokok. Semakin tinggi skor skala yang diperoleh subjek, maka perilaku merokok subjek tinggi. Sebaliknya semakin rendah skor yang diperoleh subjek, maka perilaku merokok subjek rendah.

2. Skala Persepsi Terhadap Iklan Rokok

Skala persepsi terhadap iklan rokok merupakan skala yang disusun berdasarkan aspek-aspek iklan rokok yang dikemukakan oleh Widyatama (2005) yaitu aspek daya tarik logika atau rasional dan aspek daya tarik emosional. Semakin tinggi skor skala yang diperoleh subjek, maka persepsi terhadap iklan rokok subjek positif. Sebaliknya semakin rendah skor yang diperoleh subjek, maka persepsi terhadap iklan rokok subjek negatif.

\section{Pelaksanaan Penelitian}

Penelitian dilakukan pada tanggal 25 agustus - 29 Agustus 2014.

\section{Metode Analisis Data}

Teknis Data Analisis Statistik yang digunakan pebelitian ini adalah teknik analisis korelasi product moment dari Pearson. Data dihitung dengan bantuan komputer program SPSS MS Windows Release 16,0.

\section{HASIL DAN PEMBAHASAN}

\section{Deskripsi Data}

Data yang diperoleh dari Skala Persepsi Terhadap Iklan Rokok dan Perilaku Merokok pada remaja digunakan sebagai dasar pengujian hipotesis.

\section{a. Perilaku Merokok}

Berdasarkan data hasil penelitian, skor Perilaku Merokok akan dikategorisasikan untuk mengetahui tinggi rendahnya posisi skor subjek. Kategori untuk mengetahui tinggi rendahnya posisi skor subjek dilakukan dengan mengasumsikan bahwa skor populasi dari subjek memiliki distribusi yang normal, dengan demikian akan diperoleh skor hipotik yang terdistribusi menurut model yang normal (Azwar, 1999).

Berdasarkan kategorisasi yang dilakukan dapat diketahui bahwa perilaku merokok pada remaja masuk dalam tongkatan kategori tinggi. Terdapat 26 subjek (52\%) memperoleh nilai perilaku merokok dalam kategori tinggi, 24 subjek (48\%) memperoleh nilai dukungan keluarga kategori sedang, serta tidak ada subjek yang yang masuk dalam kategori rendah. Hasil penelitian menunjukkan bahwa rerata empirik $(97,12)$ lebih besar dari rerata hipotetik $(82,5)$.

Persepsi Terhadap Iklan Rokok 
Berdasarkan kategorisasi yang dilakukan dapat diketahui bahwa persepsi terhadap iklan rokok pada remaja tergolong tinggi yang dapat diartikan bahwa persepsi terhadap iklan rokok pada remaja positif. Sebagaimana diperlihatkan terdapat 34 subjek (68\%) masuk dalam kategori tinggi dan terdapat 1 subjek (2\%) termasuk dalam kategori rendah yang dapat diartikan bahwa persepsi terhadap iklan rokok pada remaja negatif. Sedangkan hasil penelitian menunjukkan bahwa rerata empirik $(41,12)$ lebih besar dari rerata hipotetik $(35)$.

a. Uji Normalitas

Uji normalitas dilakukan untuk mengetahui apakah variabel yang diukur memiliki sebaran normal atau tidak. Uji normalitas dilakukan dengan Teknik Kolmogorov Smirnov Z. Pedoman atau kaidah yang digunakan untuk normal tidaknya sebaran adalah jika $p>0,05$ maka sebaranya dinyatakan normal dan jika $\mathrm{p}<0,05$ maka sebarannya dinyatakan tidak normal (Hadi, 2003).

Adapun hasil uji normalitas sebaran dari variabel persepsi terhadap iklan rokok dan perilaku merokok pada remaja, adalah sebagai berikut:

1. Hasil uji normalitas perilaku merokok

Sebaran data perilaku merokok menunjukan nilai KS - Z sebesar 0.098 dan taraf signifikan sebesar 0,200 ( $\mathrm{p}>0,05)$. Berdasarkan skor yang diperoleh, dapat dismipulkan bahwa data perilaku merokok terdistribusi secara normal.

2. Hasil uji normalias persepsi terhadap iklan rokok

Sebaran data persepsi terhadap iklan rokok menunjukan nilai $\mathrm{KS}-\mathrm{Z}$ sebesar 0,108 dan taraf signifikan 0,200 ( $\mathrm{p}>0,05)$. Berdasarkan skor yang diperoleh dapat disimpulkan bahwa data persepsi terhadap iklan rokok terdistribusi normal.

\section{Uji Linieritas}

Uji linieritas dilakukan untuk menguji apakah kedua variabel mempunyai hubungan yang linier. Hasil uji linieritas menunjukan bahwa hubungan antara variabel bebas dan variabel tergantung bersifat linier dengan $\mathrm{F}$ sebesar 36,049 dan $p=0,00 \quad(p<0,05)$. Hal tersebut menunjukan adanya hubungan linier antara variabel persepsi terhadap iklan rokok dengan variabel perilaku merokok.

4. Uji Hipotesis

Setelah dilakukan uji normalitas dan uji linieritas sehingga semua prasyarat terpenuhi, maka dilakuakan uji hipotesis dengan menggunakan teknik korelasi product moment dari Pearson. Hasil analisis data menunjukan rxy $=0,626$ dan $\mathrm{p}=0,00(\mathrm{p}<$ 0,01). Berdasarkan korelasi tersebut dapat dinyatakan bahwa terdapat hubungan positif antara persepsi terhadap iklan rokok dengan perilaku merokok, maka hipotesis penelitian yang di ajukan dapat diterima. Koefisien determinasi $\left(\mathrm{R}^{2}\right)$ yang diperoleh $=0,392$ artinya sumbangan variabel persepsi iklan rokok terhadap perilaku merokok 39,2\% Hasil lampiran dapat dilihat pada lampiran.

\section{Pembahasan}

Hasil analisis korelasi product moment menunjukkan bahwa ada hubungan positif sangat signifikan antara persepsi terhadap 
iklan rokok dengan perilaku merokok pada remaja, dengan koefisien korelasi sebesar rxy = $0,626(p<0,01)$. Hal ini berarti hipotesis yang menyatakan ada hubungan positif antara persepsi terhadap iklan rokok dengan perilaku merokok pada remaja diterima. Hubungan positif antara persepsi terhadap iklan rokok dengan perilaku merokok pada remaja menggambarkan bahwa jika persepsi terhadap iklan rokok positif maka perilaku merokok pada remaja cenderung tinggi. Sebaliknya jika persepsi terhadap iklan rokok negatif maka perilaku merokok pada remaja akan cenderung rendah.

Adanya hubungan antara persepsi terhadap iklan rokok dengan perilaku merokok pada remaja sesuai dengan hasil penelitian Penelitian yang dilakukan Beach et al. (dalam Nurhayati, 2011) menunjukkan bahwa semakin tinggi paparan penggunaan rokok di film secara signifikan akan meningkatkan ekspektasi positif terhadap rokok. Hal ini memberikan arti bahwa persepsi positif terhadap iklan rokok dapat memberikan stimulasi pada remaja untuk merokok. Berdasarkan hasil penelitian ini persepsi positif terhadap iklan rokok dapat diartikan bahwa remaja menganggap iklan rokok yang menarik, remaja melihat bahwa image aktor (model) dalam iklan rokok terlihat jantan, keren, dan percaya diri. Selain itu iklan juga berperan dalam memberikan informasi tentang kualitas-kualitas rokok dari merek- merek lain.

Perilaku merokok pada remaja dapat diturunkan melalui pemberian informasi bahwa iklan rokok hanya sebagai sarana promosi produk rokok bagi industri rokok. Nurhayati (2011) Remaja yang aktif dalam organisasi dan tidak aktif dalam organisasi menganggap iklan rokok sebagai promosi produk bagi industri rokok. Pemberian informasi kesehatan dan pengetahuan tentang bahaya rokok juga dapat menjadi sarana untuk menurunkan tingkat perilaku merokok pada remaja. Penelitian yang dilakukan Tumigolung dkk, (2013) menunjukkan bahwa pendidikan kesehatan dapat meningkatkan pengetahuan dan sikap siswa tentang bahaya rokok. Nuradita \& Mariyam (2013) pendidikan kesehatan terhadap siswa tentang bahaya rokok merupakan bekal yang didapatkan siswa dalam menghindari rokok.

$$
\text { Remaja seharusnya dapat }
$$
mempersepsikan dan menilai iklan rokok secara rasional dan tidak berdasarkan emosioanalnya, serta dapat mempertimbangkan dampak-dampak dari perilaku merokok. Partodiharjo (dalam Andriani \& Purnamasari, 2011) remaja seharusnya tidak boleh merokok atau menghindari dari kebiasaan merokok karena efek dari ketagihan merokok dapat mengakibatkan tubuh kekurangan oksigen (O2), penyempitan pada pembuluh darah, meningkatkan tekanan darah, penyakit jantung, stroke, impotensi, gangguan saluran pernapasan dan lain-lain.

Persepsi remaja perokok tentang dampak merokok bagi kesehatan sangat dipengaruhi oleh pengetahuan, sumber informasi yang dimilki oleh remaja dan fenomena disekitarnya (Trirahayu, 2009). Semakin banyak informasi dan pengetahuan tentang bahaya rokok yang diketahui remaja 
maka akan mengurangi perilaku merokok. Memberikan informasi terkait dengan kesehatan merupakan suatu cara untuk mengubah kebiasaan yang dilakukan oleh individu (Baron \& Byren, dalam Andriani \& Purnamasari, 2011) dan mengurangi faktor beresiko terhadap kesehatan (Duran \& Barlow, dalam Andriani \& Purnamasari, 2011).

Berdasarkan hasil kategori yang dilakukan dapat diketahui bahwa perilaku merokok pada remaja tinggi sebagaimana diperlihatkan terdapat 26 subjek (52\%), dan 24 subjek (48\%) perilaku merokoknya sedang. Keadaan tersebut menggambarkan bahwa perilaku merokok pada remaja cenderung tinggi, dan adanya pengaruh persepsi terhadap iklan rokok yang memberikan sumbangan bagi peningkatan perilaku merokok pada remaja. Berdasarkan kategorisasi yang dilakukan dapat diketahui bahwa persepsi terhadap iklan rokok dalam tingkatan tinggi yaitu 34 subjek (68\%) dan 1 subjek (2\%) memperoleh nilai kategorisasi rendah.

Hasil analisis statistik menunjukkan adanya persepsi terhadap iklan rokok yang memberikan sumbangan sebesar 39,2\%. Hal tersebut berarti bahwa persepsi terhadap iklan rokok memberi konstribusi terhadap peningkatan perilaku merokok. Nilai persepsi terhadap iklan rokok yang didapat sebesar $39,2 \%$ tidak dapat diabaikan karena faktor iklan rokok menjadi penting bagi peningkatan perilau merokok.

Hasil penelitian ini menunjukkan bahwa persepsi terhadap iklan rokok merupakan salah satu variabel yang terbukti dapat menjadi prediktor bagi peningkatan perilaku merokok pada remaja, sehingga remaja yang merokok diharapkan dapat mengurangi perilaku merokoknya.

Berdasarkan penelitian di atas, dapat ditarik kesimpulan bahwa hipotesis yang menyatakan ada hubungan positif antara persepsi terhadap iklan rokok dengan perilaku merokok dapat diterima

\section{KESIMPULAN}

Berdasarkan analisis data dan pembahasan yang telah dikemukakan dapat ditarik kesimpulan bahwa terdapat hubungan positif antara persepsi terhadap iklan rokok dengan perilaku merokok pada remaja. Artinya Jika persepsi terhadap iklan rokok positif, maka perilaku merokok pada remaja semakin tinggi. Sebaliknya jika persepsi terhadap iklan rokok negatif, maka perilaku merokok pada remaja akan cenderung semakin rendah. Dengan demikian hipotesis yang diajukan dalam penelitian ini dapat diterima. Besarnya koefisien determinasi $=\left(\mathrm{R}^{2}\right)$ sebesar 0,392. Hal tersebut menunjukkan bahwa sumbangan variabel persepsi terhadap iklan rokok dengan perilaku merokok sebesar 39,2\%, sisanya sebesar $60,2 \%$ adalah sumbangan dari variabel lain yang juga berpengaruh pada perilaku merokok.

\section{SARAN}

1. Bagi Subjek Penelitian

Bagi subjek penelitian diharapkan agar tidak terpengaruh dengan iklan rokok. Hal ini 
dapat dilakukan dengan mengurangi keterpaparan iklan rokok serta dapat mempertimbangankan dampak buruk rokok bagi kesehatan. Membatasi diri dari keterpaparan iklan rokok dan pemahaman akan dampak merokok terhadap kesehatan diharapkan dapat mengurangi perilaku merokok pada remaja.

\section{Bagi Peneliti Selanjutnya}

Berdasarkan hasil penelitian ini diketahui bahwa sumbangan variabel bebas sebesar 39,2\% maka, bagi peneliti selanjutnya yang ingin melakukan penelitian dengan tema yang sama, disarankan melakukan penelitian dengan faktor-faktor lain misalnya pengetahuan, pengaruh orang tua, pengaruh teman dan faktor kepribadian yang dapat mempengaruhi perilaku merokok sehingga dapat diketahui besar sumbangan efektif masing-masing variabel. Jika peneliti selanjutnya ingin meneliti dengan variabel bebas yang sama, disarankan peneliti memilih variabel yang lebih khusus lagi misalnya, iklan di telivisi, radio, majalah, billboard dan lain sebagainya. Sehingga dapat di ketahui besar sumbangan dari sekian banyaknya iklan.

\section{DAFTAR PUSTAKA}

Aeni. K., \& Astuti. Y. D. (2009). Perilaku Merokok Remaja Ditinjau Dari persepsi Terhadap Merokok Dan Konformitas. Skripsi (Tidak diterbitkan). Yogyakrta: Fakultas Psikologi dan Ilmu Sosial Budaya Universitas Islam Indonesia.

Andarini, D. S., \& Purnamasari, S. E. (2011). Efektivitas Pemberian Informasi Kesehatan Reproduksi Terhadap Penurunan Perilaku Merokok Pada
Remaja Putri. Insight, 9(2), 188-203.

Ariani, R. D. (2011). Hubungan Antara Iklan Rokok Dengan Sikap Dan Perilaku Merokok Pada Remaja. Skripsi (Tidak diterbitkan). Semarang: Universitas Diponegoro.

Aritonang, M. R. (1997). Fenomena Wanita Merokok. Skripsi (Tidak Diterbitkan). Yogyakarta: Fakultas Psikologi Universitas Gadjah Mada.

Ariyani, B. (2004). Hubungan antara Kecemasan dengan Perilaku Merokok. Skripsi (Tidak Diterbitkan). Yogyakarta: Fakultas Psikologi dan Ilmu Sosial Budaya Universitas Islam Indonesia.

Asrori, M., \& Ali, M. (2006). Psikologi Remaja: Perkembangan Peserta Didik. Jakarta: Bumi Aksara.

Gusti. (2011). 16 Persen Siswa SMP dan SMA Di Kota Yogyakarta Perokok. [Online], Terdapat pada URL; http://ugm.ac.id/id/berita/339016.

persen.siswa.smp.dan.sma.di.kota.Yogya karta.perokok. [Diakses pada tanggal 21 Febuari 2014].

Hasanah, A. U., \& Sulastri. (2011). Hubungan antara dukungan orang tua, teman sebaya dan iklan rokok dengan perilaku merokok pada siswa laki-laki madrasah aliyah negeri 2 boyolali. Gaster, 8(1), 695-705.

Hurlock, B. (2000). Psikologi perkembangan: Suatu pendekatan sepanjang rentang kehidupan. Jakarta: Erlangga.

Iskandar, M. S. (2011). Pembentukan Persepsi Visual Pada Iklan Televisi. Jurnal Visualita DKV, 3(1), 1-21.

Kedaulatan Rakyat. ( Selasa, 11 Febuari 2014). Iklan Tingkatkan Perokok Remaja.

Komalasari, D., \& Helmi, A. F. (2000). Faktor-Faktor Penyebab Merokok Pada Remaja. Jurnal Psikologi, 1,37 47. 
Loviana, I., Wirawan Y. G., \& Dewi, W. A. K. (2012). Persepsi Terhadap Celebrity Endoser Pada Iklan Kosmetik Dan Minat Beli Pada Mahasiswa. Jurnal Psikologika, 17(1), 57-62.

Muetadin, Z. (2002). Remaja dan Rokok. http://www.epsikologi.com/rema.050602.html. (Online). Diakses tanggal 3 Mei 2013 Pukul 18.21 wib.

Nuradita, E., \& Mariyam. (2013). Pengaruh Pendidikan Kesehatan Terhadap Pengetahuan Tentang Bahaya Rokok Pada Remaja Di SMP Negeri 3 Kendal. Jurnal Keperawatan Anak, 1(1), 44-48.

Nurhayati. (2011). Persepsi Remaja Terhadap Iklan Rokok Dan Perilaku Merokok Di Kota Banda Aceh. Tesis (tidak diterbitkan). Yogyakarta: Universitas Gadjah Mada.

Nurlailah, N. (2010). Hubungan Antara Persepsi Tentang Dampak Merokok Terhadap Kesehatan Dengan Tipe Perilaku Merokok Mahasiswa Universitas Islam Negeri Syarif Hidayatullah Jakarta. Skripsi (tidak diterbitkan). Jakarta: Universitas Islam Negeri Syarif Hidayatullah.

Selviani,T., Rahayuni, P., Mushoffa, N., \& Ninda, R. (2003). Pengaruh Iklan Sampoerna A Mild Terhadap Minat Beli Pada Mahasiswa Fakultas Teknik Arsitektur Universitas Merdeka Malang. Jurnal Psikologi Tabularasa, 1(2), 2528.

Tumigolung, H. C. S., \& Wungouw, H., \& Onibala, F. (2013). Pengaruh Pendidikan Kesehatan Terhadap Tingkat Pengetahuan Siswa Tentang Bahaya Merokok Di SMA Negeri 1 Manado. Jurnal Keperawatan (e-Kp), 1(1), 1-7.

Walgito, B. (2004). Pengantar Psikologi Umum. Yogyakarta: Andi Offset.

Widyatama, R. (2005). Pengantar Periklanan. Jakarta: Buana Pustaka Indonesia. 